\title{
STUDY ON THE JAROSITE MEDIATED BY BIOLEACHING OF PYRRHOTITE USING Acidthiobacillus FERROOXIDANS
}

\author{
ESTUDO SOBRE A JAROSITA MEDIADA PELA BIOLIXIVIAÇÃO DA PIRROTITA \\ USANDO Acidithiobacillus FERROOXIDANS
}

\author{
Kaile ZHAO*1,2 ; Guohua GU*²; Xiaohui WANG ${ }^{2}$; Wu Yan ${ }^{2}$; Guanzhou QIU ${ }^{1}$ \\ 1. School of Minerals Processing and Bio-engineering, Central South University, Changsha-410083, China; 2. Institute of Multipurpose \\ Utilization of Mineral Resources, CAGS, Chengdu-610041, China. guguohua@126.com; zhaokaile0557@sina.com
}

\begin{abstract}
Precipitation of jarosite is a very important phenomenon that is observed in the bioleaching of pyrrhotite by Acidthiobacillus ferrooxidans (A. ferrooxidans). Jarosite is a major secondary mineral formed in acid supergene environment by oxidation of metal sulphide. The formation of jarosite could decrease leached percentage. The Eh-pH diagram of $\mathrm{FeS}_{1.12}-\mathrm{H}_{2} \mathrm{O}$ showed that the thermodynamic parameters of the jarosite were exists steadily on Eh=360 $\sim 800, \mathrm{pH}=2.8 \sim 5$, and the results of $\mathrm{pH}$ condition test is consonant with the conclusions of thermodynamic analysis. By means of XRD and SEM, it could indicate that full propagation of A. ferrooxidans in the solution is beneficial to the formation of jarosite and jarosite mediated by bacterial has a better crystalline form than that synthesized by chemical method. This study indicates that $\mathrm{pH}$ value and ferrous/ferric iron concentration are key factors affecting the formation of jarosite. Leached percentage is higher when frequency was set more than 2.0. It is crucial to minimize jarosite formation in order to increase factory's efficiency.
\end{abstract}

KEYWORDS: Pyrrhotite. Bioleaching. Acidthiobacillus ferrooxidans. Jarosite.

\section{INTRODUCTION}

Jarosite is a major secondary mineral formed in acid supergene environment by oxidation of metal sulphide. Acidthiobacillus ferrooxidans (A. ferrooxidans) occurred extensively in metal sulphide ore district that has an important effect on oxidation of metal sulphide and formation of secondary minerals (ZHANG et al., 2013, ZHU et al., 2005). However, the depositing process of jarosite during biological metallurgy of sulfide ore has more harmful impact. Jarosite formation has negative effects on many applications that require the use of $A$. ferrooxidans, especially in the biological process of gas desulphurization and biological metallurgy of sulfide ore (JENSEN et al., 1995). Also, jarosite formation in coal desulfurization results in residual sulfur, which cannot be removed from coal (DAOUD et al., 2006). So it is crucial to minimize jarosite formation in order to increase efficiency and it has enlightenment function to practical industry production.

There are several factors that play a role in rate of oxidation of ferrous ions by $A$. ferrooxidans. These factors include ferrous/ferric iron concentration, cell and oxygen concentrations, $\mathrm{pH}$, temperature and reactor type. Moreover, the $\mathrm{pH}$ has significant effects on the formation of jarosite which produced during bioleaching of pyrrhotite (DAOUD et al., 2006, GU et al., 2013, POGLIANI et al., 2000, SONDI et al., 2001).

Several studies have been conducted in order to determine the importance of jarosite formation in bioreactors. But their same method is that studying on the jarosite during cultivation of bacteria (GAO et al., 2007, GU et al., 2013, POGLIANI et al., 2000, ZHENG et al., 2005, ZHU et al., 2005), such as A. ferrooxidans and $L$. ferrooxidans. Nevertheless, no experience on the production of jarosite by bio-metallurgy of sulfide ore that has been studied.

The main goal of this study was to investigate jarosite precipitation under different conditions and analyze the formation of thermodynamics condition to mediate precipitation of jarosite, and this results will be very important for determining the environment of ore leaching for minimize jarosite precipitation. Besides, for revealing the role of $A$. ferrooxidans in natural process of jarosite formation more reasonably, this paper was designed for leaching ore experiment, analysis of chemical and biogenic cause on the jarosite, combining with XRD and SEM, and had a further research on the effect of A. ferrooxidans on the jarosite formation in natural process. Study on the deposit production in leaching process was more according to practical geochemistry process, and it provides reference for practical production. 


\section{MATERIAL AND METHODS}

\section{Jarosite formation}

A. ferrooxidans can obtain energy from the oxidation of different inorganic substances, the most common substance is ferrous sulfate. The overall biochemical reaction of the oxidation of ferrous ions is

$$
4 \mathrm{Fe}^{2+}+\mathrm{O}_{2}+4 \mathrm{H}^{+} \stackrel{T . f}{\longrightarrow} 4 \mathrm{Fe}^{3+}+2 \mathrm{H}_{2} \mathrm{O}
$$

This bioreaction took a great part in practical process (DAOUD et al., 2006).

Since there is consumption of hydrogen ions, the $\mathrm{pH}$ of the liquid media initially increased. However, while this $\mathrm{pH}$ was increased, counteracted by the hydrolysis of ferric iron. Therefore, it is quite visible that the $\mathrm{pH}$ of the system has an effect on the extent of the oxidation and hydrolysis reactions. Furthermore, there is a reaction in competition with the hydrolysis reaction giving products of basic ferric hydroxysulphates with the formula $\mathrm{MFe}_{3}\left(\mathrm{SO}_{4}\right)_{2}(\mathrm{OH})_{6}$, where $\mathrm{M}=\mathrm{K}^{+}, \mathrm{Na}^{+}, \mathrm{NH}_{4}{ }^{+}, \mathrm{Ag}^{+}$, or $\mathrm{H}_{3} \mathrm{O}^{+5,6}$. These hydroxysulphate precipitates were known as jarosites. The following is the formula for jarosite precipitation:

$\mathrm{M}^{+}+3 \mathrm{Fe}^{3+}+2 \mathrm{SO}_{4}{ }^{2-}+6 \mathrm{H}_{2} \mathrm{O} \longrightarrow \mathrm{MFe}_{3}\left(\mathrm{SO}_{4}\right)_{2}(\mathrm{OH})_{6}+6 \mathrm{H}^{+}$
Since the $9 \mathrm{~K}$ medium or leaching solution contains a high concentration of $\mathrm{NH}_{4}{ }^{+}$ions, the jarosites were produced in ammoniojarosites form with formula $\mathrm{NH}_{4} \mathrm{Fe}_{3}\left(\mathrm{SO}_{4}\right)_{2}(\mathrm{OH})_{6}$ (WANG et al., 2005, WANG et al., 2006).

\section{Thermodynamics analysis \\ Eh-pH diagram of $\mathrm{FeS}_{1.12}-\mathrm{H}_{2} \mathrm{O}$ system and it's analysis}

Thermodynamic analysis during the process of bioleaching sulfide minerals is one of the most important theoretical analysis. Through thermodynamic reaction analysis during the leaching process of sulfide minerals, this study is to discuss about the condition of thermodynamic during bioleaching sulfide minerals. The general thermodynamics laws of the process were analyzed by using the Eh-pH diagram of $\mathrm{FeS}_{1.12}-\mathrm{H}_{2} \mathrm{O}$ system (QIN et al., 1999).

The chemical formula of pyrrhotite is $\mathrm{FeS}_{1.12}$, all kinds of the iron compounds and sulfur compounds exist in bioleaching of pyrrhotite system. According to the Nernst equation, the possible equilibrium equations of reaction in the $\mathrm{FeS}_{1.12}-\mathrm{H}_{2} \mathrm{O}$ system have been obtained which are showed in the Table 1.

Table 1. The possible chemical equations of pyrrhotite.

\begin{tabular}{|c|c|c|}
\hline No. & Reaction Equation & Potential Equations. \\
\hline $\mathrm{a}$ & $2 \mathrm{H}^{+}+\mathrm{e}=\mathrm{H}_{2}$ & $\mathrm{E}=-0.059 \mathrm{pH}$ \\
\hline $\mathrm{b}$ & $\mathrm{O}_{2}+4 \mathrm{H}^{+}+4 e=2 \mathrm{H}_{2} \mathrm{O}$ & $\mathrm{E}=1.229-0.059 \mathrm{pH}$ \\
\hline 1 & $S+2 H^{+}+2 e=H_{2} S$ & $\mathrm{E}=0.142-0.059 \mathrm{pH}$ \\
\hline 2 & $\mathrm{HSO}_{4}^{-}+7 \mathrm{H}^{+}+6 e=\mathrm{S}+4 \mathrm{H}_{2} \mathrm{O}$ & $\mathrm{E}=0.338-0.069 \mathrm{pH}$ \\
\hline 3 & $\mathrm{SO}_{4}^{2-}+8 \mathrm{H}^{+}+6 e=\mathrm{S}+4 \mathrm{H}_{2} \mathrm{O}$ & $\mathrm{E}=0.357-0.079 \mathrm{pH}$ \\
\hline 4 & $\mathrm{SO}_{4}^{2-}+\mathrm{H}^{+}=\mathrm{HSO}_{4}^{-}$ & $\mathrm{pH}=1.9$ \\
\hline 5 & $F e^{3+}+e=F e^{2+}$ & $\mathrm{E}=0.770$ \\
\hline 6 & $\mathrm{Fe}(\mathrm{OH})_{3}+3 \mathrm{H}^{+}=\mathrm{Fe}^{3+}+3 \mathrm{H}_{2} \mathrm{O}$ & $\mathrm{pH}=1.72$ \\
\hline 7 & $\mathrm{Fe}(\mathrm{OH})_{3}+3 \mathrm{H}^{+}+e=\mathrm{Fe}^{2+}+3 \mathrm{H}_{2} \mathrm{O}$ & $\mathrm{E}=1.02-0.146 \mathrm{pH}$ \\
\hline 8 & $\mathrm{KFe}_{3}\left(\mathrm{SO}_{4}\right)_{2}(\mathrm{OH})_{6}+8 \mathrm{H}^{+}=\mathrm{K}^{+}+3 \mathrm{Fe}^{3+}+2 \mathrm{HSO}_{4}^{-}+6 \mathrm{H}_{2} \mathrm{O}$ & $\mathrm{pH}=2.80$ \\
\hline 9 & $\mathrm{KFe}_{3}\left(\mathrm{SO}_{4}\right)_{2}(\mathrm{OH})_{6}+8 \mathrm{H}^{+}+3 e=\mathrm{K}^{+}+3 \mathrm{Fe}^{2+}+2 \mathrm{HSO}_{4}^{-}+6 \mathrm{H}_{2} \mathrm{O}$ & $\mathrm{E}=0.672-0.157 \mathrm{pH}$ \\
\hline 10 & $\mathrm{KFe}_{3}\left(\mathrm{SO}_{4}\right)_{2}(\mathrm{OH})_{6}+6 \mathrm{H}^{+}+3 e=\mathrm{K}^{+}+3 \mathrm{Fe}^{2+}+2 \mathrm{SO}_{4}^{2-}+6 \mathrm{H}_{2} \mathrm{O}$ & $\mathrm{E}=0.597-0.118 \mathrm{pH}$ \\
\hline 11 & $2 \mathrm{Fe}^{2+}+1.12 \mathrm{SO}_{4}^{2-}+8.96 \mathrm{H}^{+}+7.72 e=\mathrm{FeS}_{1.12}+\mathrm{Fe}^{3+}+4.48 \mathrm{H}_{2} \mathrm{O}$ & $\mathrm{E}=0.208-0.068 \mathrm{pH}$ \\
\hline 12 & $2 \mathrm{Fe}^{2+}+1.12 \mathrm{HSO}_{4}^{-}+7.84 \mathrm{H}^{+}+7.72 e=\mathrm{FeS}_{1.12}+\mathrm{Fe}^{3+}+4.48 \mathrm{H}_{2} \mathrm{O}$ & $\mathrm{E}=0.191-0.060 \mathrm{pH}$ \\
\hline 13 & $\mathrm{Fe}(\mathrm{OH})_{3}+1.12 \mathrm{SO}_{4}^{2-}+11.96 \mathrm{H}^{+}+9.72 e=\mathrm{FeS}_{1.12}+7.48 \mathrm{H}_{2} \mathrm{O}$ & $\mathrm{E}=0.366-0.037 \mathrm{pH}$ \\
\hline 14 & $\mathrm{Fe}(\mathrm{OH})_{3}+1.12 \mathrm{HSO}_{4}^{2-}+10.84 \mathrm{H}^{+}+9.72 e=\mathrm{FeS}_{1.12}+7.48 \mathrm{H}_{2} \mathrm{O}$ & $\mathrm{E}=0.456-0.084 \mathrm{pH}$ \\
\hline
\end{tabular}


Calculation was using the parameter which is close to the leaching test system. Activities of aqueous sulphur species and iron species was $1.0 \mathrm{~mol} \cdot \mathrm{L}^{-1}$ and $0.01 \mathrm{~mol} \cdot \mathrm{L}^{-1}$, respectively. The reaction of bioleaching is usually in response on $\mathrm{pH}$ $=1.5 \sim 4.5, \mathrm{Eh}=300 \sim 900 \mathrm{mv}$, so in the Eh-pH diagram, took the $\mathrm{pH}=0 \sim 5.0, \mathrm{E}=-0.2 \sim 1.0 \mathrm{~V}$. According to the parameters which we set in the test system based on the Portland's manual data, Fig. 1 showed relations among the equilibrium reaction ( ZHANG, 2007).
The Figure 1 indicates that in the $\mathrm{FeS}_{1.12^{-}}$ $\mathrm{H}_{2} \mathrm{O}$ system, the region which sulfur deposition exists steadily was composed by $\mathrm{pH}=0, \mathrm{pH}=5$, and $1,2,3$ phase equilibrium lines. The sulfur mainly exist in the form of $\mathrm{H}_{2} \mathrm{~S}$ below the region and stable in $\mathrm{HSO}_{4}{ }^{-}$or $\mathrm{SO}_{4}{ }^{-}$form above it. From the diagram, when the $\mathrm{pH}$ is in $1 \sim 5$ and the Eh is in $400 \sim 900 \mathrm{mV}$, the elemental sulfur can not exist steadily. But in the actual extraction process, redox reactions need to overcome a certain barrier, so sulfur maybe exists in this context.

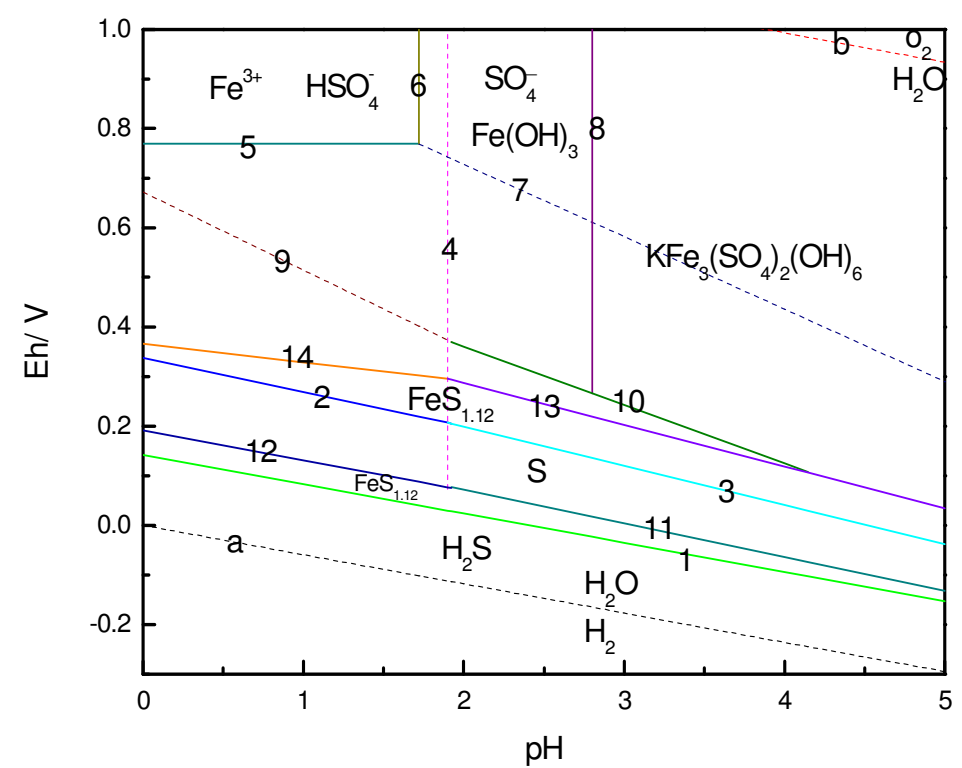

Figure 1. Eh-pH diagram for $\mathrm{FeS}_{1.12}-\mathrm{H}_{2} \mathrm{O}$ system $\left(298 \mathrm{~K}, 1.013 \times 10^{5} \mathrm{~Pa}\right)$.

$$
\left\{\alpha_{\mathrm{Fe}^{2+}}=\alpha_{\mathrm{Fe}^{3+}}=0.01 \mathrm{~mol} \bullet \mathrm{L}^{-1}, \quad \alpha_{\mathrm{K}^{+}}=0.001 \mathrm{~mol} \bullet \mathrm{L}^{-1}, \alpha_{\mathrm{HSO}_{4}^{-}}=\alpha_{\mathrm{SO}_{4}^{2-}}=\alpha_{\mathrm{H}_{2} \mathrm{~S}}=1.0 \mathrm{~mol} \bullet \mathrm{L}^{-1}\right\}
$$

The region which $\mathrm{Fe}^{3+}$ exists steadily was enclosed by the lines of 5,6 and the line of $\mathrm{pH}=0$. So we can infer that $\mathrm{Fe}^{3+}$ exists steadily when the potential was above $770 \mathrm{mv}$. When the $\mathrm{Fe}^{3+}$ reduced, the line 6 move to the right, and the region which $\mathrm{Fe}^{3+}$ exists steadily extend to the right. In practical leaching system, when $\mathrm{pH}$ is in $2.28 \sim 4.0$, Eh is in $360 \sim 800 \mathrm{mv}, \mathrm{Fe}^{3+}$ may be mainly exist in the form of precipitates ${ }^{11}$.

The Fig. 1 shows that the region which $\mathrm{KFe}_{3}\left(\mathrm{SO}_{4}\right)_{2}(\mathrm{OH})_{6}$ exists steadily was composed by $8,10,13$ phase equilibrium lines and the line of $\mathrm{pH}=5$. The stability region was above $360 \mathrm{mv}$. $\mathrm{KFe}_{3}\left(\mathrm{SO}_{4}\right)_{2}(\mathrm{OH})_{6}$ generates and exists steadily when the $\mathrm{pH}$ is more than 2.80 . Thus it is concluded that the thermodynamic parameters of the $\mathrm{Fe}_{3}\left(\mathrm{SO}_{4}\right)_{2}(\mathrm{OH})_{6}$ exists steadily were at $\mathrm{Eh}=360 \sim$ $800, \mathrm{pH}=2.8 \sim 5$. This results was also consonant with the the nether experiment of $\mathrm{pH}$ condition.
From the diagram, the regions $\mathrm{FeS}_{1.12}$ that exists steadily have two parts, one part was composed by the phase equilibrium lines of $2,3,13,14$ and the lines of $\mathrm{pH}=0, \mathrm{pH}=5$, the other part was composed by the equilibrium lines of $1,11,12$ and the lines $\mathrm{pH}=0, \mathrm{pH}=5$. The stability region was below $300 \mathrm{mv}$ and above the equilibrium line of $\mathrm{H}_{2} \mathrm{O} / \mathrm{H}_{2}$, that can be said to be stable in aqueous solution. From the two-phase equilibrium lines, we can get that the products and the intermediate products were $\mathrm{Fe}(\mathrm{OH})_{3}, \mathrm{Fe}^{2+}, \mathrm{S} \downarrow, \mathrm{H}_{2} \mathrm{~S}, \mathrm{HSO}_{4}{ }^{-}$and $\mathrm{SO}_{4}{ }^{2-}$ (OU et al., 2007).

\section{Experimental analysis \\ Equipment}

Based on procedure, the bacteria were grown in $11 \times 250 \mathrm{ml}$ Erlenmeyer flasks with the appropriate medium. The $\mathrm{pH}$ of each trial was adjusted using sulfuric acid and monitored using a $\mathrm{pH}$ meter (PH METER MODEL PHS-25).The 
bacteria were allowed to grow in a Rotary flask shaker with speed and temperature adjustment (New Brunswick Scientific Model No. HZD-C). For the ferric and total iron analyses, we used a spectrophotometer (U-Varian 9200) with the appropriate procedure. In order to detect compounds produced during bioleaching of pyrrhotite, at the end of experiment, filter paper with pore size $45 \mu \mathrm{m}$ was used to separate the jarosite produced on the wall of each flask., and air dried for X-ray diffraction(XRD), scanning electron microscopy(SEM) and energy spectrum analysis(EDS).

\section{Chemicals and metallic minerals}

All the chemicals used in this study were of analytical grade, including $10 \%$ and $20 \% \quad \mathrm{H}_{2} \mathrm{SO}_{4}$, the components of the $9 \mathrm{~K}$ medium are given in Table 2. A. ferrooxidans which we used is supply by School of Minerals Processing \& Bioengineering, Central South University. The grade of $\mathrm{Fe}$ in the pyrrhotite which used in these experiments is $57.32 \%$ and particle size is $-0.043 \mathrm{~mm}$, the XRD of pyrrhotite is shown in Fig. 2 .It can be seen that except magnetic pyrite, it also has a few extraneous components, such as quartz, metasilicate and so on.

Table 2. Components of the $9 \mathrm{~K}$ medium

\begin{tabular}{ll}
\hline Components & Contents \\
\hline$\left(\mathrm{NH}_{4}\right)_{2} \mathrm{SO}_{4}$ & $3.0 \mathrm{~g}$ \\
$\mathrm{MgSO}_{4} \cdot{ }_{7} \mathrm{H}_{2} \mathrm{O}$ & $0.5 g$ \\
$\mathrm{FeSO}_{4} \cdot{ }_{7} \mathrm{H}_{2} \mathrm{O}$ & $44.2 \mathrm{~g}$ \\
$\mathrm{~K}_{2} \mathrm{HPO}_{4}$ & $0.5 g$ \\
$\mathrm{Ca}\left(\mathrm{NO}_{3}\right)_{2}$ & $0.01 \mathrm{~g}$ \\
$\mathrm{KCl}$ & $0.1 \mathrm{~g}$ \\
$5 \mathrm{~mol} / \mathrm{l} \mathrm{H}_{2} \mathrm{SO}_{4}$ & $1.0 \mathrm{ml}$ to $\mathrm{pH}=1.8$ \\
Dist. $\mathrm{H}_{2} \mathrm{O}$ & $1000 \mathrm{ml}$ \\
\hline
\end{tabular}

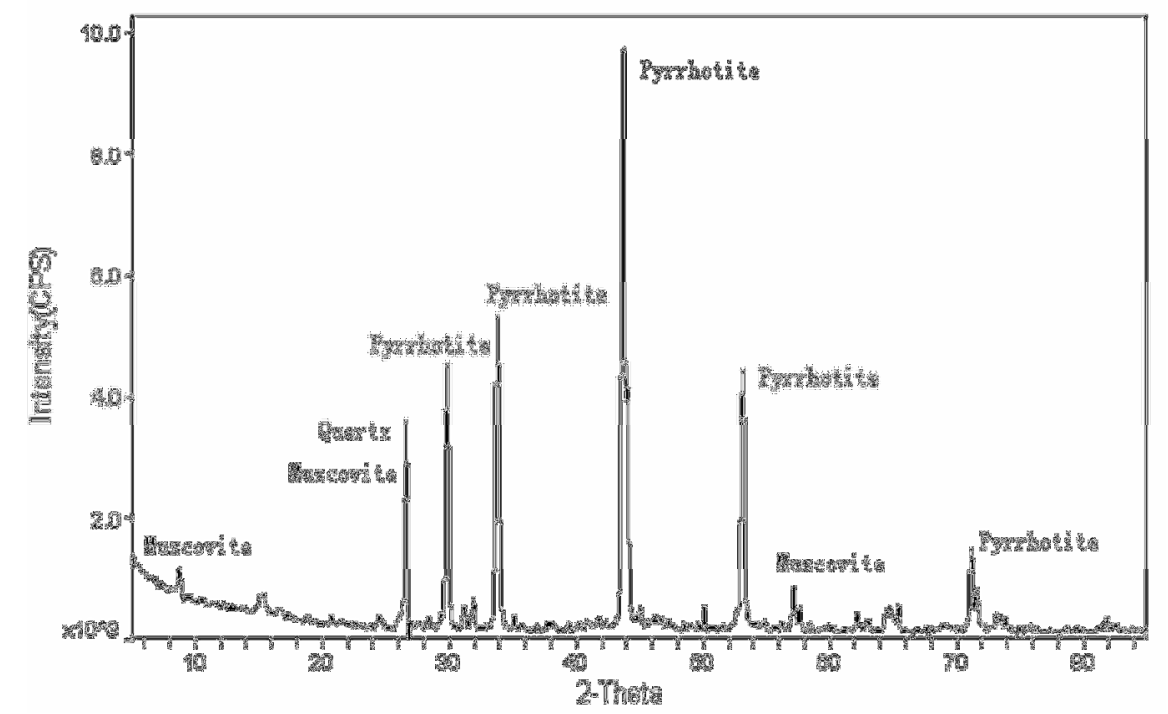

Figure 2. XRD of pyrrhotite which we used in this experimentation

\section{Experimental method}

This experiment deals with the effect of $\mathrm{pH}$ and the effect of $A$. ferrooxidans on the formation of jarosite. Therefore, the experiment was divided into two sections, dealing with varying $\mathrm{pH}$ and effect on the formation of $A$. ferrooxidans .

On this section, we discuss the effect of $A$. ferrooxidans on the formation of jarosite and analyze the different morphology of jarosite-group mediated from biologically and chemically (experiment I and II) condition and the effect of varying $\mathrm{pH}$ on jarosite formation (experiment $\Pi$ and III). As shown in Table 3, three $250 \mathrm{ml}$ Erlenmeyer flasks were used, the number for each flask is I , II and III. $150 \mathrm{ml}$ of $9 \mathrm{~K}$ medium and $5 \mathrm{~g}$ of pyrrhotite were added into each of 3 flasks. $\mathrm{pH}$ adjustment in each flask was obtained by adding $20 \% \quad \mathrm{H}_{2} \mathrm{SO}_{4}$ dropwise, with continuous agitation and $\mathrm{pH}$ measurement. Furthermore, $15 \mathrm{ml}$ of A. ferrooxidans inoculum was added to II and III flasks. The inoculum contained an average of $8 \times 10^{7}$ cells per milliliter. The flasks were then covered with pieces 
of aluminum foil. Finally, the flasks were placed in the rotary shaker at ambient temperature with 170rpm rotation speed.

Table 3. Experimental conditions in leaching of pyrrhotite

\begin{tabular}{lllll}
\hline Number & Reactants & $\mathrm{T} /{ }^{\circ} \mathrm{C}$ & Original $\mathrm{pH}$ & \multicolumn{1}{c}{ Experimental method } \\
\hline I & $9 \mathrm{~K}$, pyrrhotite & 30 & 2.0 & $\begin{array}{l}\text { Set solution } \mathrm{pH} \text { value to } 2.0 \\
\text { every two days }\end{array}$ \\
II & $\begin{array}{l}\text { 9K, 10ml A. ferrooxidans, } 5 \mathrm{~g} \\
\text { pyrrhotite }\end{array}$ & 30 & 2.0 & $\begin{array}{l}\text { Set solution pH value to 2.0 } \\
\text { every two days } \\
\text { III }\end{array}$ \\
$\begin{array}{l}9 \mathrm{~K}, \quad 10 \mathrm{ml} \text { A. ferrooxidans, } 5 \mathrm{~g} \\
\text { pyrrhotite }\end{array}$ & 30 & 2.0 & $\begin{array}{l}\text { Set solution pH value to 2.0 } \\
\text { every three days }\end{array}$ \\
\hline
\end{tabular}

\section{RESULTS AND DISCUSSION}

This experiment consisted of two parts of analysis, which are the effect of $\mathrm{pH}$ and the difference of the jarosite-group precipitates between biologically and chemically jarosite precipitation. For each parameter, we will discuss the data and observations.

Table 2 shows that Experiment $\mathrm{I}$ and Experiment $I$ is a group of comparable parallel experiment. Corresponding to the course of ore leaching, the former is the chemosynthesis producing jarosite, the latter is ore leaching producing jarosite using $A$. ferrooxidans in the same condition (SASAKI et al., 2000, ZHOU et al., 2004). In this experiment, after adding to reaction system the pyrrhotite appeared opaque deposit in the fifth day, and in the tenth day its color became deeper and turned into brownish yellow. They commonly exist in the experiment. The solid substance, that were collected from Experiment I and Experiment $\Pi$ at last, is mainly jarosite deposit showed by X-ray diffractive and EDS analysis (Fig. 3). By observing the deposit of Experiment I and II separately with SEM and EDS (Fig. 4) (DING et al., 2007, XIA et al., 2008), we can see that jarosite crystal produced in the course of acid-leaching (Experiment I) developed incompletely, had hollow holes on its surface, and its deposit was irregularly round. It may be amorphous substance; however producing deposit of bioleaching process (Experiment II ) was comparatively pure jarosite, and its crystal was regular rhombohedron and leveling the crystal face. Therefore, it is different between producing deposit and crystal degree in biological process and chemical process. Compared to the nonsterile with sterile result, we can infer that the $\mathrm{Fe}^{2+}$ fast transform by A. ferrooxidans and can cause the supply rate of $\mathrm{Fe}^{3+}$ increase in mineral surface micro area, and resulted in faster formation of jarosite crystals (GAO et al., 2007). Therefore, we got a further understanding effect of $A$. ferrooxidans on the jarosite formation in natural process.
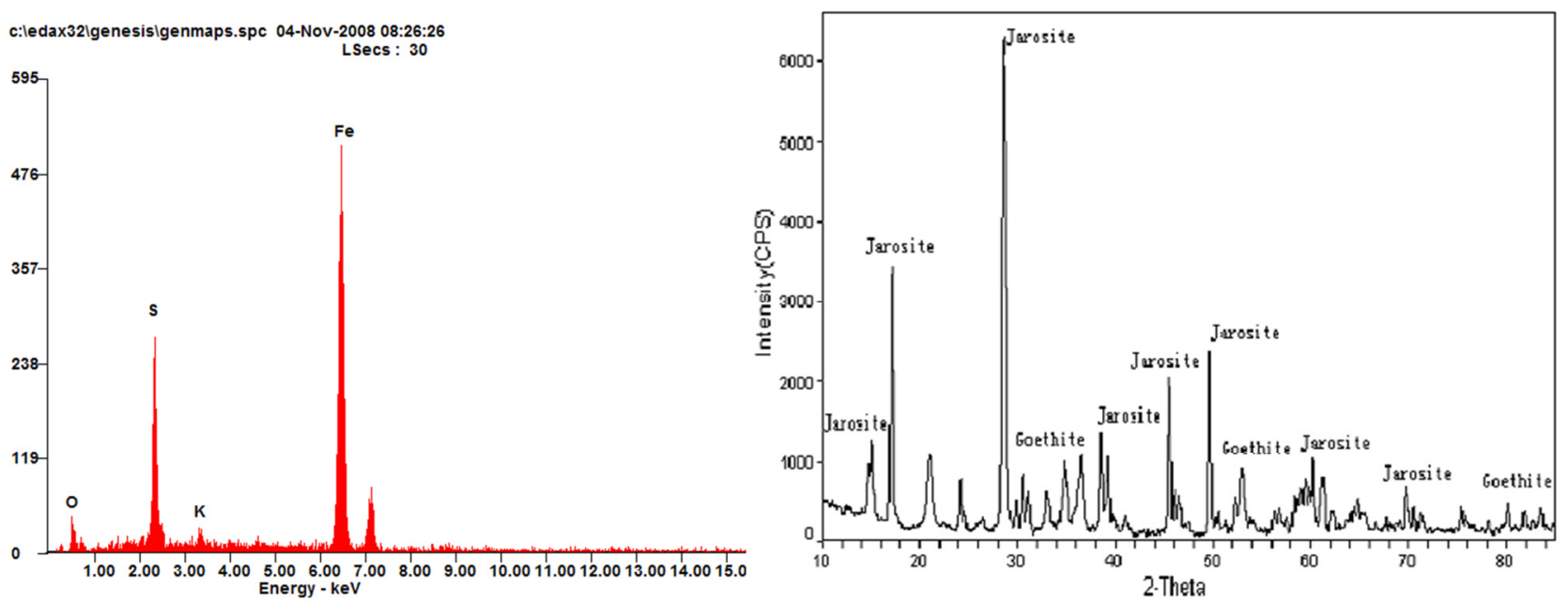

Figure 3. SEM and EDS of the jarosites from experiments I and II 


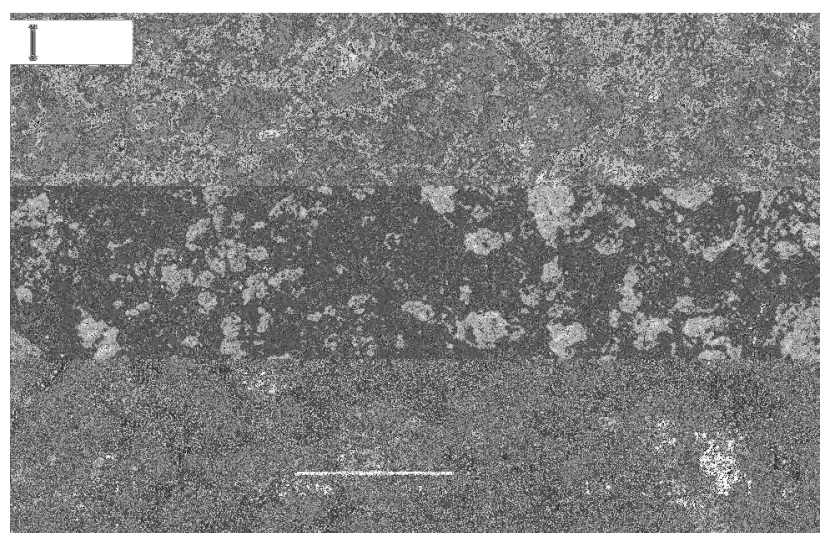

Figure 4. SEM of the jarosites from experiments I and II

Experiment II and Experiment III were also group of comparable experiment. The differences is only in regulating frequency of $\mathrm{pH}$ condition. Because $\mathrm{pH}$ value determines $\mathrm{Fe}^{3+}$ hydrolysis process directly, that it is decides whether the precursor of forming jarosite is formed, $\mathrm{pH}$ has a significant effect on the deposit forming rate. The research shows that the oxidation of pyrrhotite oxidation was fondness for acidic process, which $\mathrm{pH}$ value range from 1.8 to 2.8 the pyrrhotite produce less deposit during the process of leaching. So, when the adjustable frequence of $\mathrm{pH}$ value was higher, deposit production will be reduced. Therefore, the deposit produced in the Experiment

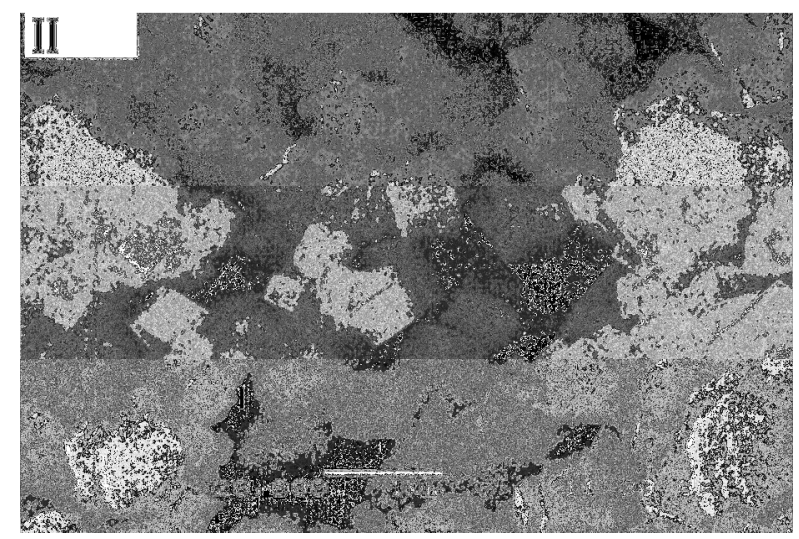

II was less than Experiment III, and because of jarosite deposit produced in the oxidation process from $\mathrm{Fe}^{2+}$ to $\mathrm{Fe}^{3+}$ by $A$. ferrooxidans. Formation of jarosite lost part of $\mathrm{Fe}^{3+}$, because $\mathrm{Fe}^{3+}$ involved in jarosite deposit, in the biological oxidation of pyrrhotite, total concentration of $\mathrm{Fe}^{3+}$ solution is less than real concentration, seriously affected the leaching rate (JIANG et al., 2007). The total concentration of $\mathrm{Fe}^{3+}$ leaching solution from Experiment II and Experiment III was assayed separately every fourth days, we obtained the change curve of leaching rate, shown on Figure 5 as follow.

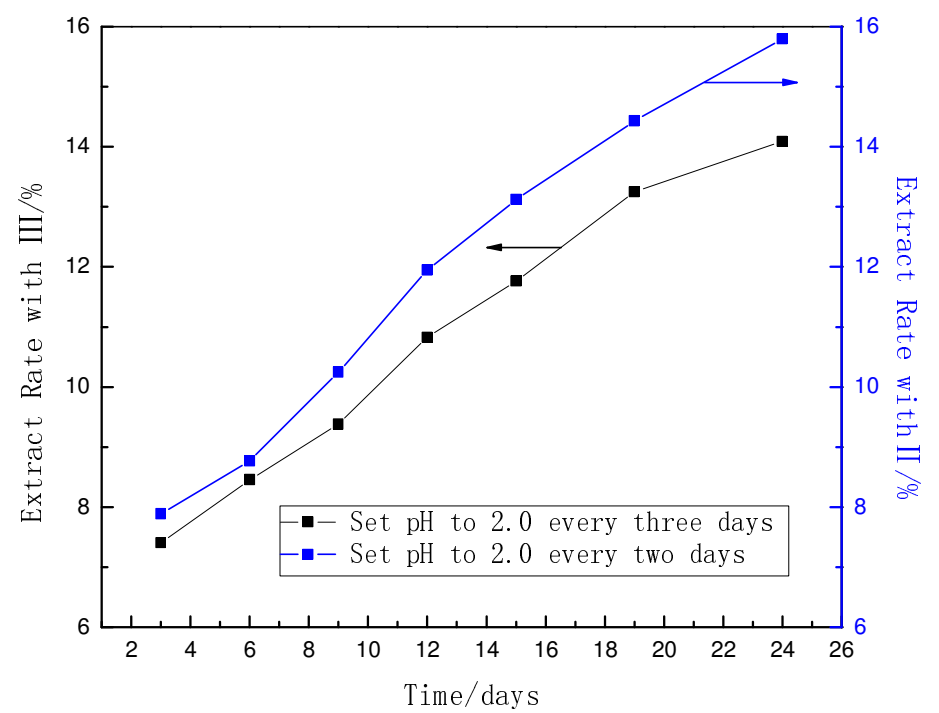

Figure 5. Change of Extract Rate with time in A. ferrooxidans leaching pyrrhotite systems

The Figure 5 shows that the leaching rate of the both rised gradually, and the leaching rate of Experiment II always larger than Experiment III. In the process of leaching pyrrhotite system, lot of jarosite precipitation were produced because of exsiting inorganic nutrient that needed for bacterial growth (such as $\mathrm{k}^{+} 、 \mathrm{Na}^{+} \mathrm{NH}_{4}^{-}$), as the leaching process was going, the $\mathrm{pH}$ and potential rase, due to $\mathrm{Fe}^{3+}$ took part in the reaction and they covered on the surface of mineral, which unfavorable to this leaching process. Therefore, controlling $\mathrm{pH}$ value appropriately can reduce the quantity of deposit forming, so as to increase the leaching rate relatively, it has enlightenment function to practical 
industry production (controlling $\mathrm{pH}$ value appropriately), and also to improve the leaching rate and production efficiency.

\section{CONCLUSIONS}

From the Eh-pH diagram of $\mathrm{FeS}_{1.12}-\mathrm{H}_{2} \mathrm{O}$, we can concluded that the conditions of jarosite that given at least $\mathrm{Eh}<360 \mathrm{mv}, \mathrm{pH}<2.8$, and the results of $\mathrm{pH}$ condition test was consonant with the conclusions of thermodynamic analysis. So when some factory acts as biological metallurgy of sulfide ore, the frequency is set to $\mathrm{pH} 1.8$, and the leached percentage was higher.

Study on the deposit production in leaching process was more in line to the practical geochemical process, it provides reference for practical production.

This paper also indicates that jarosite mediated by bacteria has a better crystalline form than that synthesized by chemical method. So we got a further understanding on the effect of $A$. ferrooxidans on the jarosite formation in natural process.

\section{ACKNOWLEDGEMENTS}

This work was supported by the National Natural Science Foundation of China (NSFC, grant Nos. 51404218, 51374249).

RESUMO: A precipitação de jarosite é um fenômeno muito importante que é observado na biolixiviação da pirrotita por Acidithiobacillus ferrooxidans (A. ferrooxidans). A jarosita é um mineral secundário principal formado no ambiente supergênico ácido pela oxidação do sulfureto do metal. A formação de jarosite pode diminuir a porcentagem de lixiviação. O diagrama de Eh-pH de FeS1.12- $\mathrm{H} 2 \mathrm{O}$ mostrou que os parâmetros termodinâmicos da jarosite estavam firmemente presentes em $\mathrm{Eh}=360 \sim 800, \mathrm{pH}=2.8 \sim 5$, e os resultados do teste de condição de $\mathrm{pH}$ estão em consonância com as conclusões da análise termodinâmica. Por meio de XRD e SEM, pode ser indicado que a propagação completa de A. ferrooxidans na solução é benéfica para a formação de jarosite e jarosite mediada por bactérias tem uma forma cristalina melhor do que a sintetizada por método químico. Este estudo indica que o valor do $\mathrm{pH}$ e a concentração de ferro ferroso/férrico são fatores chave que afetam a formação de jarosite. A porcentagem de lixiviação é maior quando a frequiência foi ajustada a mais de 2,0. É crucial para minimizar a formação de jarosite, a fim de aumentar a eficiência da fábrica.

PALAVRAS-CHAVE: Pirrotita. Biolixiviação. Acidithiobacillus ferrooxidans. Jarosite.

\section{REFERENCES}

DAOUD J, KARAMANEV D. Formation of jarosite during Fe2+ oxidation by Acidithiobacillus ferrooxidans. Minerals Engineering, v. 19, p. 960-967. 2006. http://www.sciencedirect.com/science/article/pii/S0892687505004139 . https://doi.org/10.1016/j.mineng.2005.10.024

DING JIAN-NAN, GAO JIAN, WU XUE-LING, ZHANG CHENG-GUI, WANG DIA-ZUO, QIU GUANZHOU. Jarosite-type precipitates mediated by YN22, Sulfobacillus thermosulfidooxidans, and their influences on strain. Transactions of Nonferrous Metals Society of china, v. 17, p. 1038-1044. 2007. http://d.wanfangdata.com.cn/Periodical/zgysjsxb-e200705029 . https://doi.org/10.1016/S1003-6326(07)602222

GAO JIAN, PENG HONG, LI BANG-MEI, WU XUE-LING, DING JIAN-NAN, QIU Guan-zhou. Discrepant analysis of iron precipitate synthesized by two strains of different iron-oxidizing bacteria. The Chinese Journal of Nonferrous Metals, v. 3, p. 453-458. 2007.

http://lib.cqvip.com/qk/97361X/200703/24092597.html

GU G H, HU K T, ZHANG X, XIONG X X, YANG H S. The step wise dissolution of chalcopyrite bioleached by Leptospirillum ferriphilum. Electrochimica Acta. v. 103, p. 50-57. 2013.

http://www.sciencedirect.com/science/article/pii/S0013468613007068 .

https://doi.org/10.1016/j.electacta.2013.04.051 
GU G H, YANG H S, WANG C Q. Bioleaching of pyrrhotite by moderately and extremely ther mophilic bacteria. Advanced Materials Research. v. 825, p. 274-279. 2013.

http://xueshu.baidu.com/s?wd=paperuri:(24cda59ee5a695465c75e75858b7f924)\&filter=sc_long_sign\&sc_ks_ para $=\mathrm{q} \% 3 \mathrm{D}$

JENSEN A B, WEBB C. Ferrous sulfate oxidation using Acidthiobacillus ferrooxidans: a review. Process Biochemistry, v. 30 , p. 225-236. 1995. http://www.sciencedirect.com/science/article/pii/0032959295850031 . https://doi.org/10.1016/0032-9592(95)85003-1

JIANG LEI, ZHOU HUAI-YANG, PENG XIAO-TONG. Bioleaching of pyrite ,chalcopyrite and pyrrhotite using Acidthiobacillus ferrooxidans. Science Bulletin, v. 52, p. 1802-1813. 2007.

https://www.researchgate.net/publication/225615345

OU LE-MING , HE RONG-QUAN , FENG QI-MING. Pyrite Leaching in Germ-free System and Thermodynamic Analysis. Nonferrous Metals, v. 59, p.87-90. 2007. http://xueshu.baidu.com/s?wd=paperuri:(c0605ffe6558e802a2033cf712cece35)\&filter=sc_long_sign\&sc_ks_p ara $=\mathrm{q} \% 3 \mathrm{D}$

POGLIANI C, DONATI E. Immobilisation of Acidthiobacillus ferrooxidans: importance of jarosite precipitation. Process Biochemistry. Process Biochemistry, v. 35, p. 997-1004. 2000.

http://xueshu.baidu.com/s?wd=paperuri:(401c26fec3169c75932d27c5ff8c0bad)\&filter=sc_long_sign\&sc_ks_p ara $=q \% 3 D$. https://doi.org/10.1016/S0032-9592(00)00135-7

QI F J, FENG Y L, LI H R. Leaching characteristics and recovery method of nickel from low-grade nickelpyrrhotite. Journal of University of Science and technology Beijing, v.33, p. 1065-1070. 2011.

http://d.wanfangdata.com.cn/Periodical/bjkjdxxb201109005

QIN WEN-QING, QIU GUANZHOU, XU JIN. Electrodepostion and adsorption of dixanthogen on the surface of pyrrhotite electode. China Mining magazine, v. 1, p, 73-76. 1999.

http://xueshu.baidu.com/s?wd=paperuri:(24847af0cb183fa3a42065ef90c04c1f)\&filter=sc_long_sign\&sc_ks_pa $\mathrm{ra}=\mathrm{q} \% 3 \mathrm{D}$

SASAKI K, KONNO H. Morphology of jarosite-group compounds precipitated from biologically and chemically oxidized Fe ions. Canadian Mineralogist, v.38, p. 45-56. 2000.

http://xueshu.baidu.com/s?wd=paperuri:(12a8da9d2a0c5fc627eaa72f65848960)\&filter=sc_long_sign\&sc_ks_p ara $=$ q\%3D . https://doi.org/10.2113/gscanmin.38.1.45

SONDI I, SNI S, MATIJEVIC E. Precipitation of monodispersed basic iron(III) sulfate (sodium jarosite) particles. Colloid Polym Sci, v. 279, p. 161-165. 2001.

http://xueshu.baidu.com/s?wd=paperuri:(1e8eb034f6836fbf1c0587649652be09)\&filter=sc_long_sign\&sc_ks_p ara $=q \% 3 D$. https://doi.org/10.1007/s003960000401

WANG CHANG-QIU, MA SHENG-FENG, LU AN-HUAI. Experimental study on formation conditions of ammoniojarosite and its environmental significance . Acta Geologica Sinica, v. 80, p. 296-301. 2006.

http://xueshu.baidu.com/s?wd=paperuri:(a715c2762612c71ce1f39dd5fd182ea0)\&filter=sc_long_sign\&sc_ks_p ara $=\mathrm{q} \% 3 \mathrm{D}$

XIA LE-XIAN, LIU JIAN-SHE, XIAO LI, ZENG JIA, LI BAN-MEI, GENG MEI-MEI, QIU GUAN-ZHOU. Single and cooperative bioleaching of sphalerite by two kinds of bacteria-Acidithiobacillus ferriooxidans and Acidithiobacillus thiooxidans. Transactions of Nonferrous Metals Society of china, v. 18, p. 190-195. 2008. http://xueshu.baidu.com/s?wd=paperuri\%3A\%28c27c13d0b0bd8d59ae0b015ad9e8b009\%29\&filter . https://doi.org/10.1016/S1003-6326(08)60034-5 
ZHENG YU, DI JIN-SHEN, LIU YAN-HUA, LI YING-JIE, HU BIN. Study of precipitation produced during culture of Thiobacillus ferrooxidan. Biotechnology, v. 15, p. 66-69. 2005.

http://xueshu.baidu.com/s?wd=paperuri:(e00c831eced09af1f91c1ed84561c3e8)\&filter=sc_long_sign\&sc_ks_p ara $=\mathrm{q} \% 3 \mathrm{D}$

WANG Chang-qiu, MA Sheng-feng, LU An-huai, ZHOU Jian-gong. The formation conditions of jarosite and its environmental significance. Acta Petrologica Et Mineralogica, v. 24, p. 607-611. 2005.

http://en.cnki.com.cn/Article_en/CJFDTotal-YSKW200506021.htm

ZHANG X, GU G H, HU K T, QIU G Z. Differences of Bioleaching of Pyrites from Different Geo-genetic Depositsby Leptospirillum ferriphilum. Advanced Materials Research . v.825, p. 326-330. 2013.

http://xueshu.baidu.com/s?wd=paperuri:(24cda59ee5a695465c75e75858b7f924)\&filter=sc_long_sign\&sc_ks_ para $=\mathrm{q} \% 3 \mathrm{D}$

ZHANG YAN-SHENG, The bioleaching of low grade copper sulphide ore. Central South University :Master Graduate Paper. 2007.

ZHOU SHUN-GUI, ZHOU LI-XIANG. Biosynthesis and characterization of jarosite. Spectroscopy and Spectral Analysis, v. 24, p. 1140-1143. 2004.

http://en.cnki.com.cn/Article_en/CJFDTOTAL-GUAN200409032.htm

ZHU CHANG-JIAN, LU JIAN-JUN, LU XIAN-CAI, WANG RU-CHENG, LI QI. SEM study on jarosite mediated by Acidthiobacillus ferrooxidans . Geological Journal of China Universities, v.11, p. 234-238. 2005. http://en.cnki.com.cn/Article_en/CJFDTOTAL-GXDX200502010.htm 